\title{
Lacto-fermented Kenaf (Hibiscus cannabinus L.) seed protein as a source of bioactive peptides and their applications as natural preservatives
}

\begin{abstract}
Kenaf seeds are a promising source of natural preservatives for food applications due to their potential as a substrate to generate peptides with high antibacterial activity. We sought to generate bioactive peptides with antibacterial activity from Kenaf seed proteins via lactofermentation. The ground seeds were defatted and protein extracted using acid precipitation. Kenaf seed protein was fermented with Lactobacillus casei for $72 \mathrm{~h}$ at $37^{\circ} \mathrm{C}$, and the antibacterial activity, MIC, and MBC were determined using a 96-well microtiter plate assay. The fermented protein was subjected to fractionation and peptide identification using reversedphase high pressure liquid chromatography and liquid chromatography-mass spectrometry, respectively. The fermented protein showed high antibacterial activity against Salmonella typhimurim, Escherichia coli, Psedomonas aerginosa, Staphylococcus aureus, Bacilus subtilis, and Streptococcus pyogenes. The MIC value was $4 \mathrm{mg} / \mathrm{mL}$ against all tested pathogens and the $\mathrm{MBC}$ value was $8 \mathrm{mg} / \mathrm{mL}$ against $\mathrm{S}$. typhimurium, $\mathrm{P}$. aureginosa, and E. coli and $4 \mathrm{mg} / \mathrm{mL}$ against B. subtilis, S. aureus, and S. pyogenes. Fraction 17 demonstrated the strongest antibacterial activity (98\%-100\%), and five peptides sequences were identified in this fraction. The findings of this study demonstrated high potential for kenaf seed protein fermented using Lactobacillus casei as a source of natural preservatives for a broad range of food applications.
\end{abstract}

Keyword: Kenaf seeds; Bioactive peptides; Antimicrobial; Food application; Preservation 